the behavioural ecology of the bat species identified here should help to improve protection of the great apes from Ebola virus. Human infection directly from fruit bats might in part be countered by education, as these animals are eaten by local populations living in the outbreak regions.

Eric M. Leroy ${ }^{\star}$, Brice Kumulungui ${ }^{\star}$,

Xavier Pourrut ${ }^{\star}$, Pierre Rouquet*,

Alexandre Hassanint, Philippe Yaba*,

André Délicat ${ }^{\star}$, Janusz T. Paweskał̌,

Jean-Paul Gonzalez\$, Robert Swanepoelł

*Centre International de Recherches Médicales

de Franceville, BP 769 Franceville, Gabon

e-mail: eric.leroy@ird.fr

†Muséum National d'Histoire Naturelle, UMR

5202, Paris 75005, France

†National Institute for Communicable Diseases,

Special Pathogens Unit, Private Bag X4,
Sandringham 2131, South Africa

§̧Institut de Recherche pour le Développernent, UR178, Mahidol University at Salaya,

Nakhonpathom 73170, Thailand

1. Pournut, X.et a. Microbes Infect. 7, 1005-1014 (2005)

2. Walsh, P. D.et a. Nature 422, 611-614 (2003).

3. Leroy, E.M.etal. Sclence 303, 387-390 (2004).

4. Geisbert, T.W.et al. Am. J. Pathal. 163, 2347-2370 (2003).

5. Bergmans, W. Beaufortia 39,89-152 (1989)

6. Swanepoel, R, Leman P.A.\& Burt, F.L Emerg Infect. Dis.2. $321-325$ (1996)

7. Sanchez, $A_{7}$ Killey, M.P. Klenk, H-D.\& Feldmann $H .1$ Gen Viral. 73, 347-357 (1992)

8. Halpin K, Young, P. L. Field, H.E.\& Mackenzie, LS.J.Gen Viral. 81, 1927-1932 (2000)

9. Anguin, P.M. etal. Emerg Infect. Dis. 8, 258-262 (2002).

10. Langevin, P. \& Barklay, R. M. R. Mammal. Species 357, 1-4 (1990).

Sup plementary information accompanies this communication on Nature's web site

Competing financial interests: declar ed none. dob:101038/438575a

\title{
PALAEOECOLOGY
}

\section{A gigantic fossil arthropod trackway}

A unique, complex trackway has been discovered in Scotland: it was made roughly $330 \mathrm{mil}$ lion years ago by a huge, six-legged water scorpion that was about $1.6 \mathrm{~m}$ long and a metre wide. To my knowledge, this is not only the largest terrestrial trackway of a walking arthropod to be found so far, but is also the first record of locomotion on land for a species of Hibbertopterus (Eurypterida). This evidence of lumbering movement indicates that these giant arthropods, now extinct, could survive out of water at a time when the earliest tetrapods were making their transition to the land.

The trackway (Fig. 1a, b) is exposed on a bedding plane close to the base of a sandstone section in a non-marine sequence. It is $6 \mathrm{~m}$ long, $0.90-0.98 \mathrm{~m}$ wide and consists of sinuous, paired belts of appendage prints flanking a sub-central groove. The trace-maker had at least three pairs of appendages of different lengths (heteropodous), which moved in phase. The longest, outer limbs left elongated crescent-shaped prints (series A in Fig. 1b, green), which overlap slightly or coalesce into a linked series of arcs. The stride length is therefore less than the series-A print length (average, $0.27 \mathrm{~m}$ ) and indicates that the animal was crawling extremely slowly.

Lines of elongate, crescentic or sigmoidal prints (series B in Fig. 1b, blue) lie inside series $A$, and further elliptical prints (series $C$ in Fig. 1b, yellow), made by the shortest appendages, can be detected inside these. In places, the series-C prints have been erased by the central groove, which was made by the posterior part of the animal. This is trapezoidal in cross-section and its base is deeper at the margins and slightly raised in the centre. Occasional oblique lineations on the sides and base of the groove indicate that the motion was jerky. The sinuous curve of the groove is smaller in amplitude than, and out of phase with (by about $0.5-0.6 \mathrm{~m}$ ), the trackway margins, which reveals the direction of locomotion (Fig. 1a, b). The slow, stilted progression, together with the dragging of the posterior, indicates that the animal was not buoyant and that it was probably moving out of water.

There are several groups of Lower Carboniferous (Asbian) arthropods that might have been capable of leaving large trackways', but only the water scorpions, or eurypterids ', are likely to have left the trackway described here. The pattern and character of the limb prints is most consistent with a relatively short-limbed and markedly heteropodous hibbertopteroid eurypterid ${ }^{2-5}$ (Fig. 1c). The double-keeled underside of the terminal tail plate of these animals ${ }^{45}$ matches the character of the central groove.

Fragmentary exoskeletal remains of $\mathrm{Hib}$ bertopterus and related forms are relatively well known from Scottish Lower Carboniferous rocks ${ }^{2-5}$ and were first described from West Lothian in 1831 (ref. 2). The trackwaymaker (Fig. 1c) would have been comparable in size to the largest known hibbertopteroid body fossils, which have head shields ${ }^{3-5}$ that are $0.65 \mathrm{~m}$ wide.

The short length of the relative stride in the trackway emphasizes the extreme slowness of the gait and differentiates it from other eurypterid trackways within the ichnogenus Palmichnium $^{1,6-9}$. This trace is $0.2 \mathrm{~m}(25 \%)$ wider than any other trackway of this type ${ }^{1}$. The only larger known invertebrate trackway, although also attributed to a eurypterid, is very different in character and appears to have been made by a swimming animal ${ }^{10}$.

Martin A. Whyte
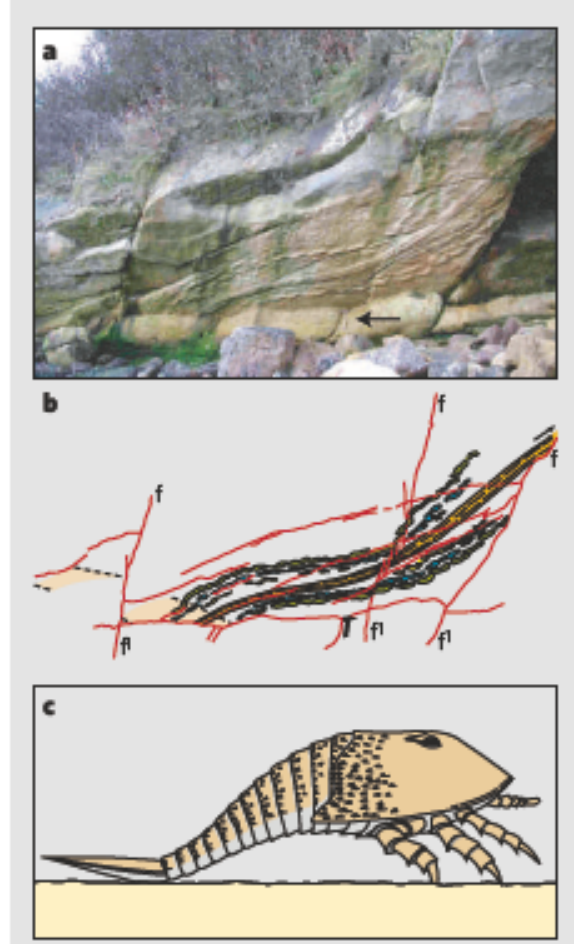

Figure 1 | Hibbertopteroid trackway from Lower Carboniferous (Asbian) rocks in Scotland.

a, Vlew of the trackway on the undersurface of an overhanging sandstone bed, which is dipping at $45^{\circ}$ away from the viewer. The hammer (arrowed) in the photograph is $30 \mathrm{~cm}$ long, but the oblique view affects scale and relative proportions. b, Interpretive diagram showing track features, position of a second, smaller ( $0.80 \mathrm{~m}$ wide) trackway and the position in the rock of microfaults ( $\mathrm{f}-\mathrm{f}^{\mathrm{l}}$ ), joints and bedding traces (red lines). Arrow indicates movement direction of the animal. Trackway: orange, central groove; series A, B and C are shown in green, blue and yellow, respectively. $c$, Reconstruction of the hibbertopteroid eurypterid trackway-maker. This arthropod was about $1.6 \mathrm{~m}$. long (for clarity, the limbs on the left of the body are omitted).

Department of Geography, University of Sheffield, Brookhill, Sheffield S10 2TN, UK

e-mait: ma.whyte@sheffieldacuk.

1. Briggs, D. E G. \& Rolfe, W.D. L J. Paleantol.57,377-390 (1983).

2. Weterston C.D. Trans. R. Soc. Edinh 61, 265-288 (1957).

3 Waterston, C.D. Tans. R. Soc. Edinh 68, 1-20 (1968)

4. Jeram, A.I \& Selden, PA. Trans. R. Soc. Edinh. E 84, 301-308 (1994).

5. Selden, P. A. Corronca, L A.\& Hänicken M.A. Bial. Lett. 1, 44-48(2005)

6. Braddy, S I\& Milnec, A.E.Can J. Earth Sd. 35 , $116-1122$ (1998)

7. Braddy, S I.\& A Imond, I.E. J. Afr. Earth Sci. 29, 165-177 (1999).

8. Draganits, E, Braddy,S.J.\& Briggs, D. E G Palaios 16, $126-147$ (2001)

9. Hanken, N. M.\& Stormer, L. Foss. Strata 4, 255-270 (1975).

10 Almond, 1 E Geobuletin 45, 28 (2002).

Competing financial interests: declared none. doi:10.1038/438576a

BRIEF COMMUNICATIONS ARISING online I www.nature.com/bca see Nature contents. 